\title{
FGFR3 Gene Translocation
}

National Cancer Institute

\section{Source}

National Cancer Institute. FGFR3 Gene Translocation. NCI Thesaurus. Code C150619.

A cytogenetic abnormality that refers to any translocation involving the FGFR3 gene. 